\title{
ある種の混合整数計画問題への内点法の応用*
}

\author{
沢井 一智 ·佐伯 修† ·过 毅一郎 $\ddagger$
}

\section{An Application of the Interior Point Method to some Mixed Integer Programming Problems*}

\author{
Kazunori SAWAI ${ }^{\dagger}$, Osamu SAEKI ${ }^{\ddagger}$ and Kiichiro TsuJI ${ }^{\ddagger}$
}

\begin{abstract}
Mixed Integer Programming (MIP) problems are widely used. They are generally solved by the branch and bound method. It requires much calculation time to solve these problems. The first relaxed problems of MIP problems occasionally have several optimal basic solutions. In this paper, we propose a method which is an application of the interior point method to the branch and bound method for these problems. It is shown that the proposed method has an advantage over the conventional method. A numerical study on the optimal operation problem of the cogeneration system which is one of MIP problems shows that the proposed method reduces the number of subproblems and the computational time.
\end{abstract}

\section{1. 緒論}

現在，様々な分野で $0-1$ 混合整数計画問題が利用され ている。たとえば設備の起動・停止を考慮したシステム の最適運用問題や施設配置問題などがある。これらの問 題は，より複雑な問題の部分問題として定式化される場 合や対象とするシステムの複雑化などにより大規模化す る場合があり，多くの計算時間を必要としている.

一方，最適化手法については，離散变数を扱う問題の 中でも全整数計画問題に対して切除平面法の有効性が示 されている [1]ものの, 混合整数計画問題に対しては有 効なカットを生成するのが難しいとされている [2]. その ため別のアプローチとして, 分枝限定法と切除平面法を 組み合わせた手法 [3,4] が研究されている. Balas ら [3] は各部分問題でカットを効果的に付加する方法を提案し ているが，分枝限定法よりも計算時間の点で劣る場合も あることが指摘されており, 計算時間の短縮の点から問 題がある。また, Van Roy ら [4]は，まず有効なカット を生成し，その後分枝限定法を用いる手法を提案してい

\footnotetext{
* 原稿受付 2000 年 5 月 1 日

†関西電力 (株) Kansai Electric Power Co. Inc.

‡ 大阪大学 大学院 工学研究科 Graduate School of Engineering, Osaka University; 2-1 Yamada-oka, Suita, Osaka 565-0871, JAPAN

Key Words: interior point methods, branch and bound methods, mixed integer programming problems, optimal operation problems, optimization.
}

るが，この手法では効果のでない問題も多くあることが 指摘されて抢り, 計算アルゴリズムのロバスト性の点で 問題がある。このような現状のため, 一般的な 0-1 混合 整数計画問題は分枝限定法 [5] を使用して解く場合が多 いが，パラメー夕によっては解が得られるまでに膨大な 計算時間を要する場合もあり, 計算時間の短縮ならびに 計算アルゴリズムのロバスト性の改善が望まれている.

分枝限定法に打いては, 通常 $0-1$ 整数变数の一部を 0 または 1 に固定し，他の 0-1整数变数を 0 以上 1 以下の 連続変数にした緩和問題を解く必要がある。この緩和問 題は一般的な線形計画問題であり通常は単体法を用いて 解かれる。 そこで，この部分に内点法などの高速解法を 適用すれば分枝限定法そのものが高速化されると期待で きるが，その効果は自明ではない，その理由は, 分枝限 定法に扔いて単体法を使用する場合, 最初の緩和問題は いわゆるコールドスタートで解き, 2 回目以降の緩和問 題は前回得られた解を利用したいわゆるホットスタート で解くからである。一般に内点法ではホットスタートの 効果は大きくない.したがって, 内点法では最初の緩和 問題に対しては計算時間の短縮が期待できるものの, 2 回目以降では計算時間短縮効果は期待できない。

しかしながら，筆者らの経験によるとコージェネレー ションシステム最適運用問題 [6]のような問題では, 緩和 問題の最適解は複数ある場合が多い.これは, 一部の $0-1$ 整数变数の目的関数の係数が 0 であるため, 最適解にお 
いて 0-1 整数变数に設定の自由度が生じるためと考えら れる。このような問題の特性はコージェネレーションの 最適運用問題に限らず発生すると考えられる。このよう な問題に対し, 最初の緩和問題には内点法を, 2 回目以 降の問題には単体法を適用する手法を考える.最初の緩 和問題に最適解が複数ある場合, 単体法と内点法では必 ずしも同一の最適解に到達するとは限らない. とくに内 点法では, いわゆる基底回復を施して最適解を求めるた め, 基底回復に用いる手法によって, 異なる最適解に到 達させることができる．このことは， 2 回目以降の分枝・ 限定操作は, 単体法と内点法で異なることを意味してい る.もし, 内点法で 2 回目以降解くべき䋧和問題の数を, 単体法を用いる場合より減少させることができれば，内 点法の適用により計算時間の短縮ならびにアルゴリズム のロバスト性の改善が達成できるものと考えられる。

本論文では, 上述のような特徵を持つ 0-1 混合整数計 画問題を分枝限定法により解く場合, 最初の緩和問題に 内点法を用いると, 基底回復操作のため 2 回目以降に生 成する部分問題の数を減少させることができることを示 す。また，提案手法により計算時間の短縮ならびに計算 アルゴリズムのロバスト性の改善が図れることをコー ジェネレーションシステム最適運用問題へ適用した数值 実験により明らかにする。

\section{2. 分枝限定法における内点法の応用}

\section{1 内点法を取り入れた分枝限定法}

以下のような 0-1 混合整数計画問題を考える.

Problem (P)

Minimize $\quad c^{\mathrm{T}} x$

Subject to $A x=b$

$$
\begin{aligned}
& x_{i} \in\{0,1\}, \quad i=1, \cdots, n_{Z} \\
& x_{i} \geq 0, \quad i=n_{Z}+1, \cdots, n
\end{aligned}
$$

ここで, $A \in R^{m \times n}, \operatorname{rank}(A)=m, b \in R^{m}, c \in R^{n}$ である.

この問題 $(\mathrm{P})$ を分枝限定法を用いて解く場合, まず問 題 $(\mathrm{P})$ のすべての 0-1 整数变数を 0 以上 1 以下の連続変 数とした緩和問題 $\left(\mathrm{P}^{\prime}\right)$ を生成する.

Problem ( $\left.\mathrm{P}^{\prime}\right)$

Minimize $\quad c^{\mathrm{T}} x$

Subject to $A x=b$

$$
\begin{aligned}
& 0 \leq x_{i} \leq 1, \quad i=1, \cdots, n_{Z} \\
& x_{i} \geq 0, \quad i=n_{Z}+1, \cdots, n
\end{aligned}
$$

分枝限定法では, 最初に問題 $(\mathrm{P})$ の連続緩和問題 $\left(\mathrm{P}^{\prime}\right)$ を解く、緩和問題が実行不可能であるとき, および䋧和 問題の最適解が現段階の暫定解以上であるときは, 元の 問題の最適解がその部分問題の配下にはないので見切 りを行う。また，0-1 整数変数の值がすべて 0 または 1 であり, 現段階で最もよい目的関数值を持っているなら ば, その解を暫定解とする。つぎに, 緩和問題の最適解 で 0 と 1 の間の值をとっている 0-1 整数变数が存在する 場合は, その 0-1 整数変数を選択し，0 または 1 に固定
した部分問題を新たに生成する (分枝操作). 以降，未処 理の部分問題がなくなるまで再帰的に上述の操作を繰り 返す．以上が分枝限定法の基本的な手順である．分枝限 定法では部分問題の選択方式ならびに分枝变数の選択方 式が実行時間に大きな影響を与えることが知られている が，個々の問題の構造に依存する場合が多く一般の場合 に普遍的によいと認められている選択方式はない [7]. 本 論文では, 分枝変数の選択方式として対象問題の 0-1 変 数のうち 0 でも 1 でもない変数のなかから添字順に選ぶ 方式を用いる。また，未処理の部分問題の選択方式には 深さ優先則や最良下界則が有名であるが, 記憶すべき情 報量が少ない等の利点のある深さ優先則を用いる。

2 回目以降の部分問題は, 親の緩和問題の最適基底を 初期基底として緩和問題の最適解を求めることが可能で ある。そのため, ホットスタートによる高速化が期待で きる。つまり，計算時間を最も必要とする問題はホット スタートが利用できない最初の緩和問題である。そこで 本論文では, 分枝限定法の最初の緩和問題のみに内点法 を利用し， 2 回目以降ではホットスタートが利用できる 単体法を利用する。単体法を利用するためには，2 回目 スタート時の最適基底を出す処理が必要となってくる. その方法は以下のとおりである。まず内点法で得られた 最適解から基底変数の候補を選択し，得られた基底解が 最適解でない場合はピボット操作を繰り返し最適基底を 算出する。このように内点法で得られた最適解から最適 基底を導出する処理を以後基底回復と呼ぶ. また, 内点 法にはさまざまな種類のものが提案されているが, 理論 的な収束特性が良いことや実際の問題での計算時間が短 いこと, ならびに任意の内点を初期点とすることが可能 であることから現在広く利用されているプレディク夕. コレクタ法 [8] を用いる.

Fig. 1 に本論文で用いる内点法を適用した分枝限定法 の処理フローを示す.

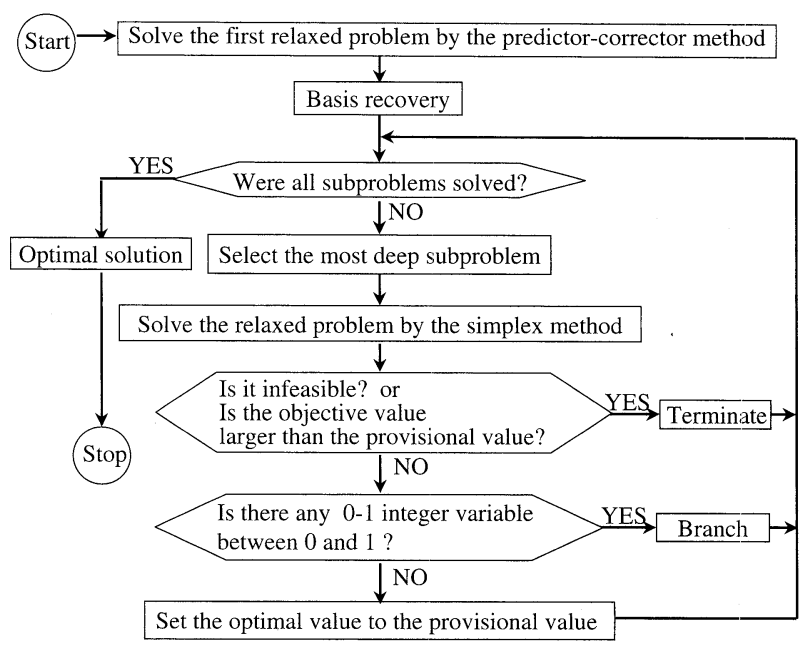

Fig. 1 Flowchart of the proposed method with the interior point method 


\section{2 単体法に対する内点法の優位性}

緩和問題の最適解が複数存在する 0-1 混合整数計画問 題に内点法を応用した場合, 基底回復での基底の選択方 式により得られる最適端点が変わるものと考元られる。 分枝限定法では, 0 と 1 の間の值をとる 0-1 整数变数を 0 または 1 に固定した部分問題を順次生成する。そのため, 基底回復でより多くの 0-1 整数変数が 0 または 1 の值に なるような最適端点を導出することで 2 回目以降での部 分問題の生成を抑制できるものと考えられる。一方, 単 体法の最適解からは，部分問題生成数を減少させるよう な最適端点を導くのは困難であると考えられる。このこ とを以下に示す。

まず，以下のような一つの 0-1 整数変数 $\left(x_{1}\right)$ を含む混 合整数計画問題 $(\mathrm{MIP})$ を考える.この問題で $x_{1}$ を 0 以 上 1 以下とした連続緩和問題は最適解を複数もっており, Fig. 2 のような最適平面上のすべての点が最適解となる.

$$
(\mathrm{MIP}) \begin{cases}\text { Minimize } & x_{3} \\ \text { Subject to } & 2 x_{1}+x_{2}-x_{4}=1.2 \\ & x_{1}+2 x_{2}-x_{5}=1.2 \\ & x_{1}-x_{2}+x_{6}=0.6 \\ & x_{1}+x_{2}+x_{7}=1.7 \\ & 2 x_{1}-x_{2}+x_{8}=1.6 \\ & x_{1}+2 x_{2}+x_{9}=2.5 \\ & -2 x_{1}+3 x_{2}+x_{10}=2 \\ & x_{1}+s_{1}=1 \\ & x_{1} \in\{0,1\} \\ & x_{i} \geq 0, \quad i=2, \cdots, 10 \\ & s_{1} \geq 0\end{cases}
$$

問題 (MIP)の制約条件はすべて等式制約となっており, $0-1$ 整数变数については以下の制約が課せられている.

$$
(0-1 \text { 整数変数 })+(\text { スラック变数 })=1
$$

内点法の最適解から基底回復を行う場合, この 0- 1 整 数変数㧍よびスラック変数のどちらかを非基底にするこ とで 0- 1 整数変数は 0 または 1 の値となる。一方, 単体 法の最適解から, 多くの 0-1 整数变数もしくはスラック 変数を非基底にするには，以下の方法が考えられる。

- 単体法で最適解を求めた後, 最適性条件を維持した まま， 0-1 整数変数もしくはそのスラック変数を基 底からはずし, 連続変数を基底に入れるピボット操 作を行う。

この方法により, 一回のピボット操作で必ず連続変数 を基底に入れ 0- 1 整数変数もしくはそのスラック変数を 基底からはずすことができる。しかし，この方法を用い ても問題 (MIP) の場合, 単体法の最適解から部分問題生 成数を削減する最適端点にはたどりつけないことを以下 に示す.

単体法の最適解 (1) では，0-1 整数変数およびそのス

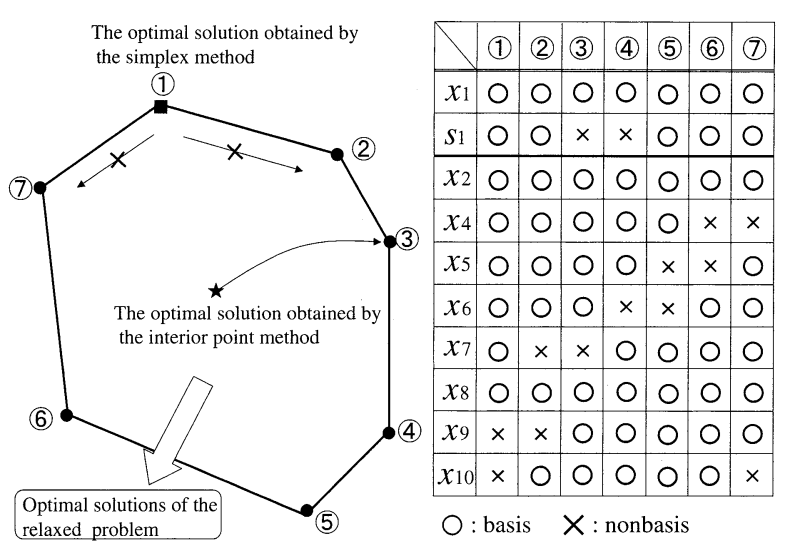

Fig. 2 Basic variables of each optimal basic solution

ラック変数はどちらも基底になっている．また，部分問 題生成数を削減する最適端点 (3), (4) では, いずれも $0-1$ 整数変数が基底に入って, スラック变数が非基底と なっている. 単体法の最適解 (1) からは連続変数同士を 入れ替えなければ，隣接端点には移動できない，すなわ ち前述の移動手順では, (1)一(2), (1)（7)へは移動でき ず, 解(3), 解(4)には到達できない. 一方, 内点法の最適 解は理論上最適平面の中心部のいわゆる解析的中心に収 束する [9]. 本論文の内点法では，ステップ幅を長くする など高速化のための改良を行っており，必ずしも理論上 の収束点に収束する保証はないが, 我々の経験上大きく 逸脱することはない，そのため, 図に示したように, 最 適平面の中心部に収束した最適解から基底回復を工夫す ることで最適端点(3)への移動が可能となる.

つまり, 内点法の最適解からは導出するのが可能であ ると考えられ，かつ部分問題数が抑制される端点に単体 法の最適解から移動させるのは困難と考えられる。よ て, 最初の緩和問題を高速に解くだけでなく, 部分問題 生成数を減少させるような最適端点を得ることができる という点でも, 内点法は単体法に対して優位であると考 えられる。

\section{3 基底回復方式}

この節では, 基底回復の方式として以下に述べる $\mathrm{A}$, $\mathrm{B}, \mathrm{C}$ のうを考える.

方式 A では, 1 回目の緩和問題の最適解で值の大きな ものから順に並べ, 制約の数だけ順次基底に選ぶ. 従属 な変数がある場合は，基底には入れないものとする。つ ぎに, 得られた基底が実行可能でない場合, ピボット操 作を繰り返して最適基底を求める。 この基底回復方式で は, 内点法の最適解で1より大きい連続変数が多い場合, 連続変数が優先的に基底に選ばれていくため, 0-1 整数 変数拉よびそのスラック変数は基底からはずれ, 部分問 題の生成数が少なくなるものと考えられる.

方式 Bでは, 正の值をもつ連続変数を值の大きい変数 から順に基底の候補に選ぶ。つぎに，正の值をもつ 0-1 整数变数揖よびスラック变数を值の大きい順に並べその 
順に基底に追加する. 選択した変数の数が制約式の数に 満たない場合は，さらに最適解で 0 と判定されたすべて の変数を值の大きい順に選択する. 方式 A と同様得られ た基底が実行可能ではない場合, ピボット操作を繰り返 し最適基底を求める. この方式では, 多くの 0-1 整数変 数およびスラック変数を, 最適解のとる值に依存せずに 基底からはずすことができ, 部分問題生成を抑制できる ものと考えられる。

方式 $\mathrm{C}$ は, 方式 Bで值が 0 と判定された変数の優先順 位を変更したものであり，対応する列の要素数が少ない 順に並び替えて，その順に基底の候補にする方式である. この方式では, 基底行列に含まれる非零要素数を少なく することで 2 回目以降の計算時間の削減が期待できる.

方式 $\mathrm{B}, \mathrm{C}$ では, 緩和問題の最適解で正の值をもつ変 数と 0 の值をとる变数とに分割する必要がある。プレ ディクタ・コレク夕法を用いた場合，この分割を求める 手法が参考文献 $[10]$ で示されている. 本論文では, 内点 法収束時の $x$ および $s$ の各要素の值により, 以下の条件 を満たす場合に変数 $x_{j}$ は正の值をもつものと判定する.

$$
\left|x_{j}-x_{j}^{\prime}\right| / x_{j}^{\prime} \leq\left|s_{j}-s_{j}^{\prime}\right| / s_{j}^{\prime}, \quad j \in\{1, \cdots, n\}
$$

ここで， $x_{j}, s_{j}$ はそれぞれ内点法収束時の主変数および 双対スラック変数の值であり, $x_{j}^{\prime}, s_{j}^{\prime}$ は 1 計算サイクル 前の值である。

\section{3. 数值実験による効果の検証}

0-1 混合整数計画問題として定式化されたガスタービ ンを主機とするコージェネレーションシステムの最適運 用問題に対して提案手法を適用した結果について述べる.

\section{1 対象問題}

コージェネレーションシステムとして, 蒸気の利用方 法がそれぞれ異なるガスタービン排熱ボイラシステム, コンバインドサイクルシステムの 2 種類のシステムを対 象とした. 目的関数には，1日 24 時間帯で考えた入力工 ネルギー（電力および都市ガス）コストおよび各機器の 起動・停止費を考慮した。また，制約には対象システム を構成する各機器の入出力関係, 入力量の上下限制約, および需給バランス制約を考えた。

以下に数值実験の対象問題の定式化を示す [6]. なお制 約条件では, 表記を簡単にするため, 時間帯を示す添字 $t$ は省略している。

- 目的関数 (最小化)

$$
\sum_{t=1}^{24}\left\{C_{b} e_{b}^{t}-C_{s} e_{s}^{t}+C f^{t}+\sum_{i=1}^{N} C_{L i}\left|\delta_{i}^{t}-\delta_{i}^{\prime} t\right|\right\}
$$

- 制約条件

- 入出力関係と入力量の上下限制約

$$
\begin{aligned}
& y_{i k}=a_{i k} x_{i}+b_{i k} \delta_{i} \quad\left(k=1, \cdots, K_{i}\right) \\
& \underline{x_{i}} \delta_{i} \leq x_{i} \leq \bar{x}_{i} \delta_{i}
\end{aligned}
$$

$\delta_{i} \in\{0,1\}$

- 需給バランス制約

$\sum q_{i}^{C}=Q^{C}$

$\sum_{i}^{i} q_{i}^{H O}=\sum_{i} q_{i}^{H I}+Q^{H}$

$e_{b}+\sum_{i} e_{i}^{O}=E+e_{s}+\sum_{i} e_{i}^{a}$

$f=\sum_{i}^{i} f_{i}$

ただし，

$K_{i}$ : 機器 $i$ の特性式の数

$x_{i}$ : 機器 $i$ の入力量, これは $f_{i}, e_{i}^{I}, q_{i}^{H I}$ のいずれかの 変数である

$y_{i k}$ : 機器 $i$ の $k$ 番目の特性式の出力変数, これは $e_{i}^{a}, e_{i}^{O}, q_{i}^{C}, q_{i}^{H O}$ のいずれかである

$i$ : 機器の識別子

$t$ : 時間帯を表す添字

$N$ : 機器の総数

$C_{b}$ : 買電の従量料金単価 [円 $/ \mathrm{MWh}$ ]

$C_{s}$ : 逆送電力の従量料金単価 [円/ $\mathrm{MWh}$ ]

$C_{L i}$ : 機器 $i$ の起動・停止時損失エネルギーコスト [円/回]

$C:$ 都市ガスの従量料金単価 [円/ $\mathrm{t}]$

$a_{i k}, b_{i k}$ : 機器 $i$ の $k$ 番目の動作特性を表す定数

$\delta_{i}$ : 機器 $i$ の運転 - 停止を表す 0-1 整数变数

$\delta_{i}^{\prime}$ : 前時刻における $\delta_{i}$

$f:$ 都市ガス消費量 $[\mathrm{t}]$

$f_{i}$ : 機器 $i$ の入力ガス量 $[\mathrm{t}]$

$\underline{f_{i}}, \overline{f_{i}}$ : 入力ガス量の下限值および上限值 $[\mathrm{t}]$

$\overline{e_{i}^{X}}$ : 機器 $i$ の入力 $\cdot$ 出力電力量 $[\mathrm{MWh}](X \in\{I, O\})$

$e_{i}^{a}$ : 機器 $i$ の補機電力量 $[\mathrm{MWh}]$

$e_{b}:$ 買電量 $[\mathrm{MWh}]$

$e_{s}$ : 逆送電力量 $[\mathrm{MWh}]$

$E:$ 電力需要量 $[\mathrm{MWh}]$

$\underline{e_{i}^{I}}, \overline{e_{i}^{I}}:$ 機器 $i$ の入力電力量の下限值および上限値 [MWh]

$q_{i}^{C}:$ 機器 $i$ の冷水出力量 $[\mathrm{Gcal}]$

$Q^{C}$ : 冷房需要量 $[$ Gcal]

$q_{i}^{H X}$ : 機器 $i$ の温水または蒸気入力 $\cdot$ 出力量 [Grcal] $(X \in\{I, O\})$

$Q^{H}$ : 暖房・給湯需要量 $[\mathrm{Gcal}]$

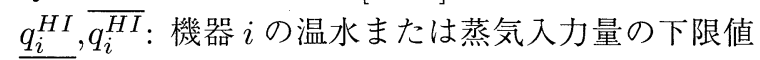
および上限值 [Gcal]

コージェネレーションシステムの構成や発電機台数お よび需要パターンの異なる, 24 個の最適運用問題を対象 問題とした. Table 1 に問題の制約条件, 変数, 0-1 整 数变数の数を示す.ここで, 問題の 1 番目の文字はシス テム方式を表し, g, c はそれぞれガスタービン排熱ボイ ラシステム，コンバインドサイクルシステムである。ま た, 2 番目の数字はシステム内の発電機台数, 3 番目の 
文字は需要を表し，w，a，uはそれぞれある住宅地の平 日, 土曜, 日曜の需要を, i は事務所の需要 $[6]$ を示して いる.なおシステム内の各機器台数は発電機台数および 需要に合わせて設定している. 数值実験は SPECint95 が6.26, SPECfp95 が9.06のワークステーション上で 行った. なお分枝限定法は，ネットワーク上で公開され ている netlib の lp-solve Ver.2.0 パッケージを用いた.

Table 1 Size of problems

\begin{tabular}{|c|c|c|c||c|c|c|c|}
\hline Problem & $m$ & $n$ & $n_{Z}$ & Problem & $m$ & $n$ & $n_{Z}$ \\
\hline g1w & 1,752 & 2,376 & 192 & c1w & 1,920 & 2,568 & 216 \\
\hline g1a & 1,752 & 2,376 & 192 & c1a & 1,920 & 2,568 & 216 \\
\hline g1u & 1,752 & 2,376 & 192 & c1u & 1,920 & 2,568 & 216 \\
\hline g1i & 1,464 & 1,944 & 144 & c1i & 1,632 & 2,232 & 168 \\
\hline g2w & 2,112 & 2,832 & 240 & c2w & 2,376 & 3,216 & 288 \\
\hline g2a & 2,112 & 2,832 & 240 & c2a & 2,376 & 3,216 & 288 \\
\hline g2u & 2,112 & 2,832 & 240 & c2u & 2,376 & 3,216 & 288 \\
\hline g2i & 1,776 & 2,352 & 192 & c2i & 2,040 & 2,856 & 240 \\
\hline g3w & 2,424 & 3,240 & 288 & c3w & 2,448 & 3,336 & 312 \\
\hline g3a & 2,424 & 3,240 & 288 & c3a & 2,448 & 3,336 & 312 \\
\hline g3u & 2,424 & 3,240 & 288 & c3u & 2,448 & 3,336 & 312 \\
\hline g3i & 2,232 & 2,976 & 264 & c3i & 2,448 & 3,336 & 312 \\
\hline
\end{tabular}

$m:$ number of constraints, $n:$ number of all variables $n_{Z}$ :number of $0-1$ variables

\section{2 部分問題生成数の減少}

部分問題の生成数を抑制するためには，2 回目スター 卜時で 0 または 1 の值をとる $0-1$ 整数变数の数を多くす ることが効果があるものと考えられる。また, 2 回目ス タート時に 0 または 1 の值をとる $0-1$ 整数変数の数が多 いほど，基底となる整数正変数の数は少なくなっている ものと考えられる. (ここで, 整数正変数とは最適解で正 の值をもち得る 0-1 整数変数およびそのスラック変数の ことをいう.）基底回復方式 B は基底に入る整数正変数 を抑制することを目指した方式である. そこで, 方式 B による効果を調べるため, 問題 $\mathrm{g}$ を各方法を用いて解い た場合の, 2 回目スタート時に基底に入っている整数正

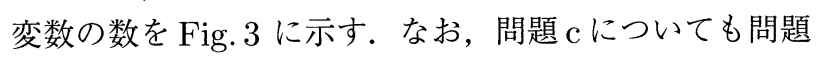
$\mathrm{g}$ と同様の結果となった.

Fig. 3 より, 方式 B では lp-solve に比べすべての問題 で基底に入っている整数正変数が少なくなっていること がわかる，また，方式 $\mathrm{A}$ と比べた場合でも，基底に入っ ている整数正変数の数が同じかもしくは少なくなってい る. 方式 $\mathrm{C}$ では, 基底回復における正の值を持った変数 に対する優先順位が方式 B と同じであるため, 基底に 入っている整数正変数は同一であり, 2 回目スタート時 点での解は同じであった。この図により, 方式 $\mathrm{B}, \mathrm{C} に$ よって基底に入る整数正変数の数が抑制できることが確 認できた.

つぎに，各方式の生成した部分問題数を Fig. 4 に示す. なお方式 $\mathrm{B}$ と方式 $\mathrm{C}$ は, すべての部分問題について最適

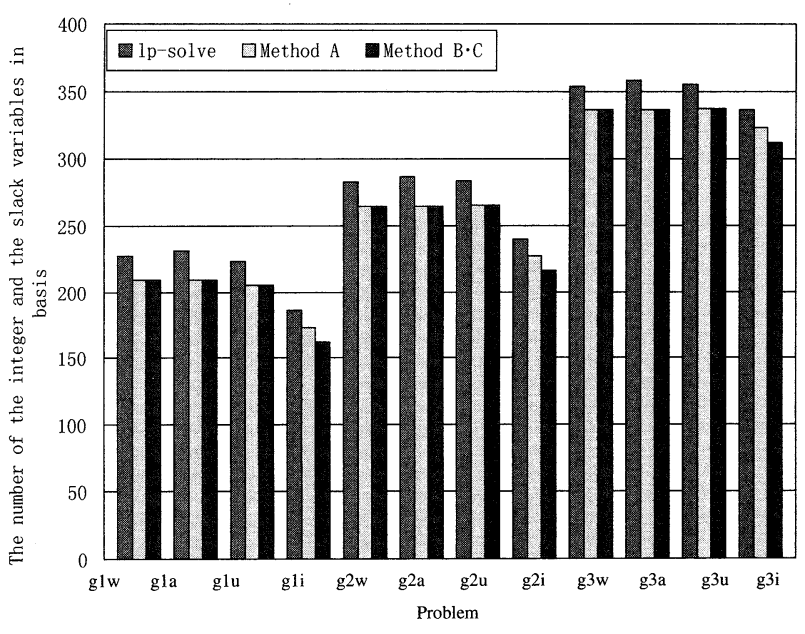

Fig. 3 The number of integer and the slack variables in basis

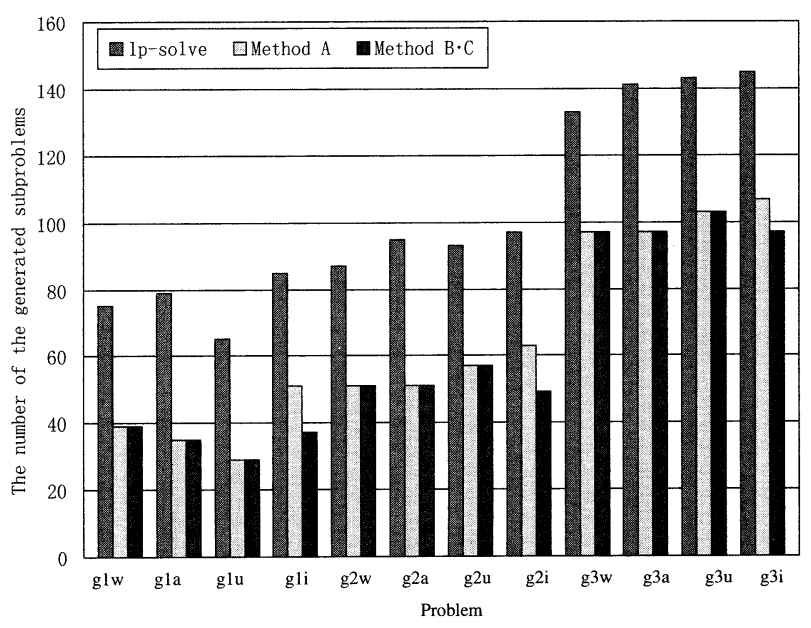

Fig. 4 The number of the generated subproblems

解が同じになった。そのため, 同一の分枝木となりすべ ての問題において部分問題生成数が一致した.

Fig. 4 より，方式Bがすべての問題に対して部分問題 生成数が最も少なくなっていることが確認できる.これ はFig. 3 に示したように基底に入る整数正变数の数を少 なくできたことで，2回目スタート時に 0 または 1 の值 をとる 0-1 整数変数の数が多くなったためと考えられる. また Fig. 4 から方式 A でも lp-solve に比べて部分問題 生成が抑制できていることが分かる. 方式 $\mathrm{A}$ の基底回復 は, 内点法で得られた最適解の値の大きなものから優先 的に基底に選択していく方式である. 方式 A で部分問題 が削減されるのは, 内点法の最適解で 1 より大きい值を もつ連続変数が多い場合と考えられる。そこで, 緩和問 題の最適解において 1 より大きい連続変数が多い場合に, 部分問題生成数が少なくなることを示す. 内点法の最適 解で正の值を持つ変数の数に対する 1 より大きな值をも つ連続変数の数の割合ならびにlp-solve に対する方式 A, 方式 B の部分問題削減率の関係を Fig. 5 に示す. Fig. 5 を見ると，需要パターンとして $\mathrm{w} ， \mathrm{a}, \mathrm{u}$ を用いた問題の 多くで, 正の值をもつ変数の $50 \%$ 前後が 1 より大きい連 
続変数であることが分かる. そのため, これらの問題で は方式 A を用いることで基底回復で多くの連続変数が優 先的に基底に選ばれ, 部分問題生成数が方式 B と同程度 削減されたものと考えられる。一方, 需要パターン $\mathrm{i}$ 用いた問題では，1より大きい変数の割合が $20 \%$ 程度で ある.これらの問題でも, 方式 Aがlp-solveより部分問 題生成数が減少しているが，この問題に連続変数から優 先的に基底に選ぶ方式 Bを用いることにより，さらに部 分問題生成数が削減できていることが確認できる。よっ て, 方式 B は最適解の值の大きさによらず部分問題削 減効果があり，数值的にロバストな方式であると考えら れる。

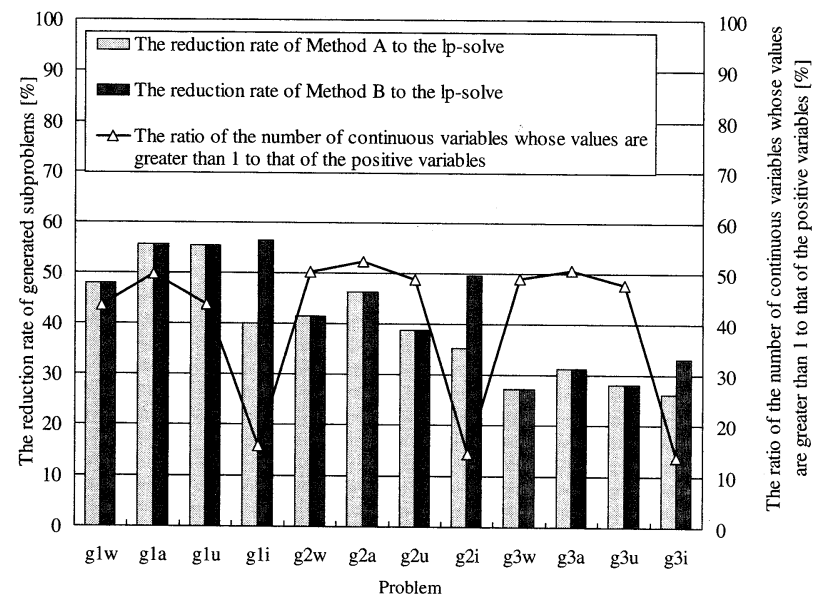

Fig. 5 The reduction rate of the generated subproblems

\section{3 計算時間短縮効果}

本節では lp-solve と方式 A, B, C を比較し, 内点法 による計算時間の短縮効果を確認する。また，方式 $\mathrm{A}$, $\mathrm{B}, \mathrm{C}$ の優劣についても考察する. 問題 $\mathrm{g}$, 問題 $\mathrm{c} に$ にお る計算時間をそれぞれ Fig. 6, Fig. 7 に示す.

各手法での計算時間の内訳が分かるように, lp-solve では 1 回目, 2 回目以降にかかる計算時間に, 方式 A, $\mathrm{B}, \mathrm{C}$ では 1 回目, 基底回復, 2 回目以降にかかる計算時

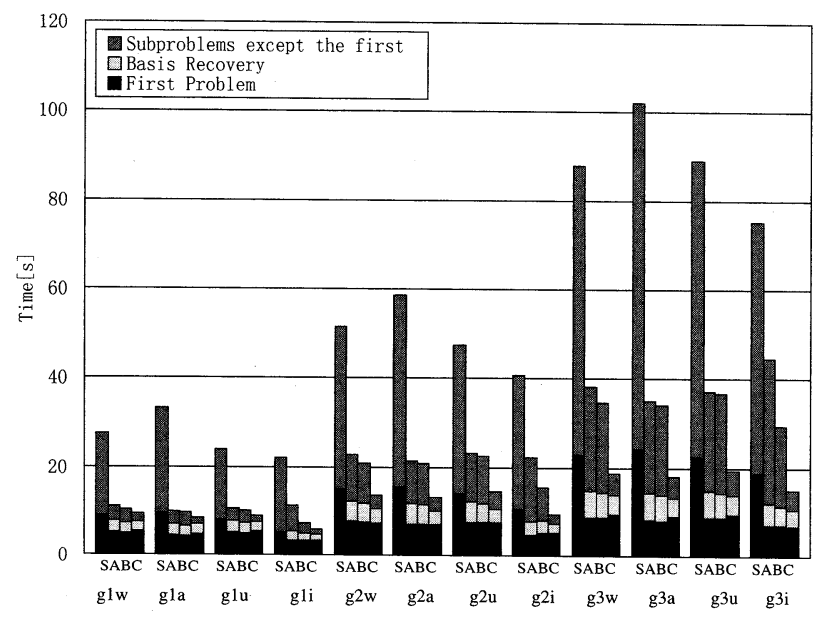

Fig. 6 Calculation time (Problem g)

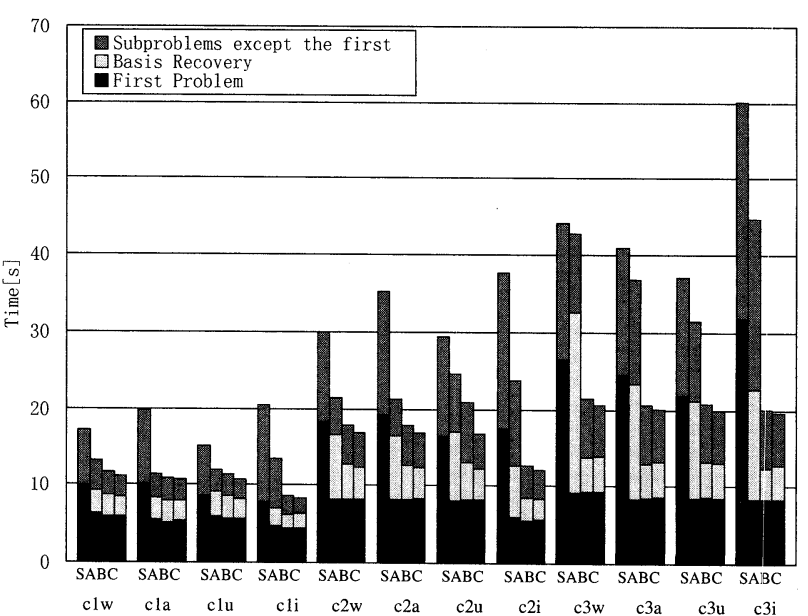

Fig. 7 Calculation time (Problem c)

間に分けて示す。また図中の' $\mathrm{S}$ 'はlp-solveを表し, 'A', 'B'，'C'はそれぞれ方式 A，B，Cを表す。

Fig. 6, Fig.7 を見ると，方式 A，B，Cを用いること でlp-solve に比べ，すべての問題で全体の計算時間が削 減されていることが分かる。これは, 内点法を用いるこ とで 1 回目にかかる計算時間を半分程度にできたことや 生成する部分問題数を削減できたこと, および 2 回目以 降の計算時間が削減できたためである．計算時間削減効 果が最も大きいと考えられる方式 C と lp-solve を比較し た場合，約 $30 \%$ から $80 \%$ の計算時間が削減されている。

つぎに各方式ごとの比較を行う。まず，方式 A と方式 $\mathrm{B}$ を比較した場合，方式 B はすべての問題で方式 A より 計算時間が短くなっている。 とくに, 部分問題生成数が 削減されている g1i，g2i，g3i では，計算時間も大きく 削減されている。

また，方式 B と方式 C を比較した場合，すべての問題 で方式 Cのほうが計算時間が短く, とくに，2 回目以降 の計算時間の差が大きいことが分かる. 方式 C は, 基底 行列に含まれる要素数をできるだけ少なくする方式であ る.そこで 2 回目スタート時での基底行列の非零要素数 が 2 回目以降の計算時間に影響していることを確認する.

Fig. 8 に, 方式 B と方式 Cで 2 回目スタート時の基底 行列の列シングルトンの数の差と方式 Bに対する方式 $\mathrm{C}$ の 2 回目以降の計算時間削減率の関係を示す.なお横軸 は方式 Cの列シングルトン数から方式 B の列シングルト ン数を差し引いたものを列全体の大きさで割ってスケー リングしたものである。

Fig. 8 から, 列シングルトン数の差が大きくなると 2 回目以降の計算時間削減率が大きくなる傾向にあること

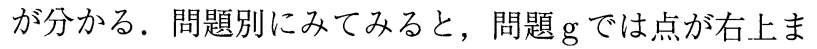
であるのに対し, 問題 c では左下にかたまっており, 問題 によって方式Cの効果が大きく異なっている。 また, 列 シングルトンの数の差がない場合でも計算時間に $10 \%$ 程 度の差が生じている問題があるが，これは列シングルト ン以外の非零要素数の削減による計算時間の削減効果と 


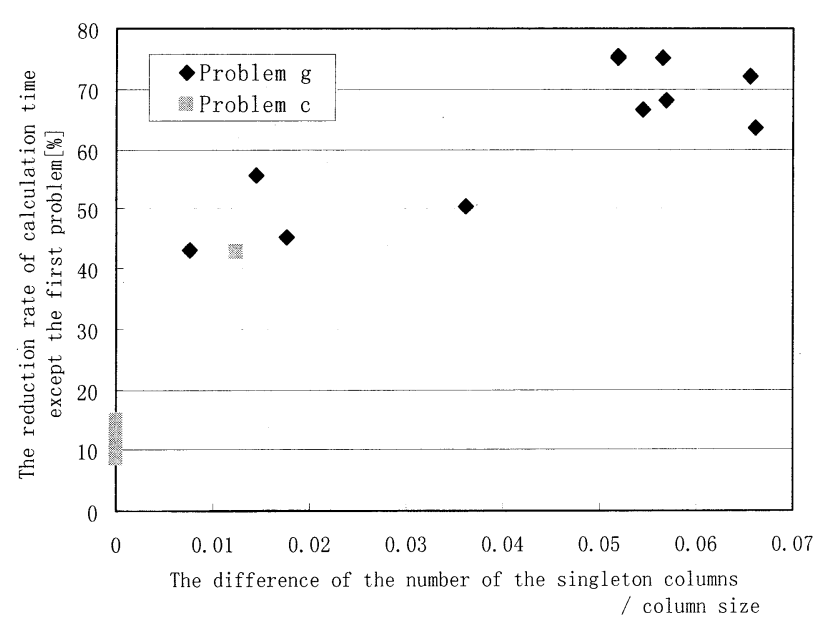

Fig. 8 The relationship between the number of the singleton columns and the reduction rate of calculation time

考えられる. 以上のことから，方式 C を用いることで基 底行列の非零要素数を少なくし, それにともない列シン グルトンの数を多くでき, 2 回目以降の計算時間削減に 貢献していることが確認できた.

\section{4. 結論}

本論文では, 緩和問題の最適解が複数存在する問題を 分枝限定法により解く場合, 最初の緩和問題に内点法を 用い, 内点法の基底回復を工夫すると, 2 回目以降生成 する部分問題の数を減少させる端点を導くことができる ことを示した。一方, 単体法を用いるといったん最適解 を見つけてから, 部分問題生成数を減少させる最適端点 を導くのは困難であることを確認し，単体法に対する内 点法の優位性を示した。またコージェネレーションシス テム最適運用問題に対する数值実験により, 単体法のみ を用いたlp-solveに対し，内点法を用いた手法のすべて の方式で部分問題生成数が削減されることを示した。計 算時間では, lp-solveに対し内点法を用いた手法すべて で計算時間が削減され，1回目の緩和問題の計算時間を 削減できたこともあり, 最も効果が表れる方式 Cでは lp-solve に対し，全体で約 30\%から約 80\%の計算時間が 削減された。

本研究の一部は日本学術振興会未来開拓学術研究推進 事業 (JSPS-RFTF97P01002) による援助を受けて行わ れた。

\section{参考文献}

[1] C. Ceria, C. Cordier, H. Marchand and L. A. Wolsey: Cutting plane for integer programs with general integer variables; Mathematical Programming, Vol. 81, pp. 201-214 (1998)

[2] X. -Q. Yan and E. A. Boyd: Cutting planes for mixed-integer knapsack polyhedra; Mathematical Programming, Vol. 81, pp. 257-262 (1998)

[3] E. Balas, S. Ceria and G. Cornuejols: Mixed 0-1 programming by lift-and-project in a branch and cut framework; Management Science, Vol. 42, pp. 12291246 (1996)

[4] T. J. Van Roy and L. A. Wolsey: Solving mixed 01 programs by automatic reformulation; Operations Research, Vol. 35, pp. 145-163 (1987)

[5] O. Guieu and J. W. Ghinneck: Analyzing infeasible mixed-integer and integer linear programs; INFORMS journal on Computing, Vol. 11, pp. 63-77 (1999)

[6] 伊東, 横山：コージェネレーションの最適計画, 産業図 書 (1993)

[7] 坂和：離散システムの最適化, 森北出版（2000）

[8] S. Mehrotra: On the implementation of a primal-dual interior point method; Society for Industrial and Applied Mathematics, Vol. 2, No. 4, pp. 575-601 (1992)

[9] C. Roos, T. Terlaky and J. -Ph. Vial: Theory and Algorithms for Linear Optimization, John Wiley \& Sons Ltd (1997)

[10] S. Mehrotra and Y. Ye: Finding an interior point in the optimal face of linear programs; Mathematical Programming, Vol. 62, ṕp. 497-515 (1993)

[11] 日本コージェネレーションセンター: コージェネレーショ ンシステム年間動向レポート (1998 年度), 日本コージェ ネレーションセンター (1999) 